\title{
各種突患に於ける尿中フォルマリン生成ステロイドの消長
}

\author{
金濢大日置肉科笠屈宗夫 \\ Studies on the Excretion of Formaldehydogenic Steroids \\ in the Urine in Various Diseases. \\ Muneo Kasazima
}

\begin{abstract}
緒 ·論

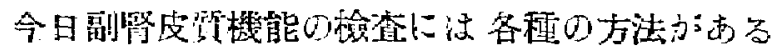

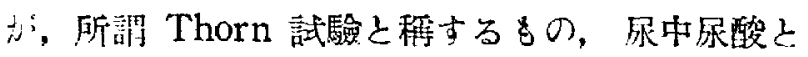

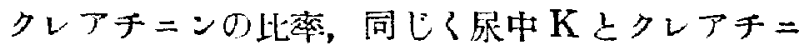
ン比率，インシュリンブドー糖附箈血糖曲線，ブ

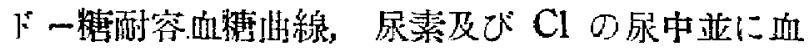
樂中测定を行つて或種の比を算出せんとするもの (Robinson 試驗)，血䐐中O $\mathrm{Na}, \mathrm{Cl}, \mathrm{K}, \mathrm{P}$ 等然機 物の湖定，血漿中ヒョレステリン價，アルブミン

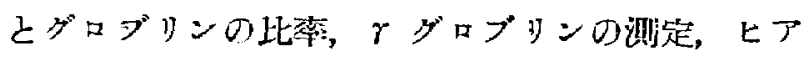
ルロニダーゼフルオレスチン皮虔試驗等はいすれ も間接的ですり，須可らくはホルモン自体の测定

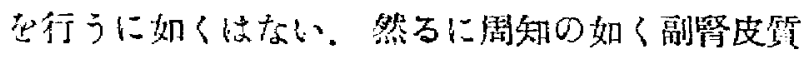
に於いて見出される6糧の生物學的活性ステロロイ

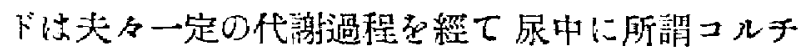
コイド及び17くトステロイドの型に於て排泄せら 凡当，節古今之等ステロイドの尿中排湿量によつ

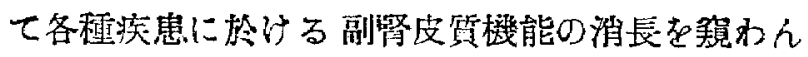

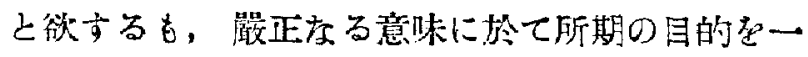
氣に洼し得られるものではない，蒀に之等化署的 に定量せられるステロイド住生物學的に活性なる もの，非活性なるもの含め，副腎の機能及び之 に閶する代謝過程の炛計尼表わすに過ぶないのて

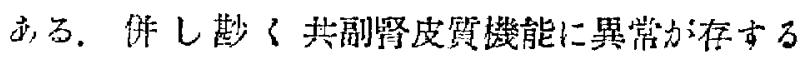

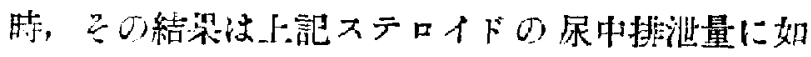
惯に現われ得べき事澢然の事であつて，斯る化

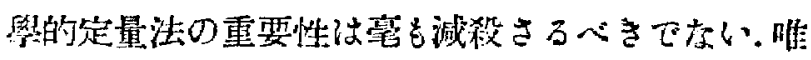
此際尿中の如何なるステロイド在教象之して检索

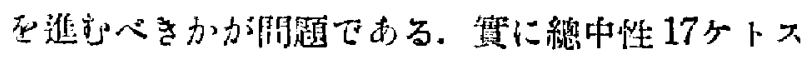

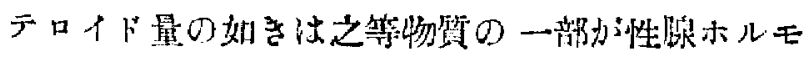

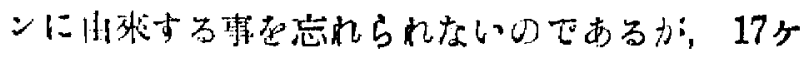
トステロイドに於ては或虫るのアルコール性を济
\end{abstract}

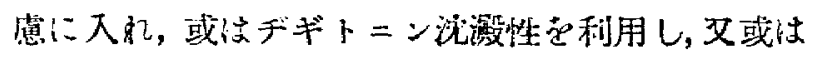
フルフロール是色及應を適用して己の融督性の。 の捕捉することも出來病いでない。然も之に比

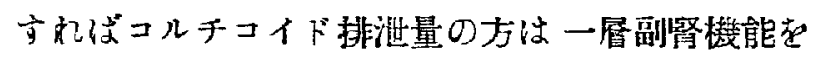
よく代表与るものの如く思考せられる。後者の测 定に當つても，或は還元力を應用し第二銅イオン 引至数モリブデン酸を用いる方法，或は過沃素酸

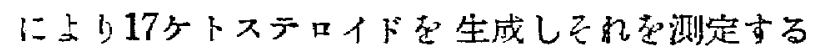
法, 艾或虻その際生するフオルムアルデヒドを測

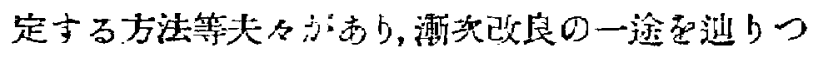
つまるものであるか，之等軦近の方法に依り多數

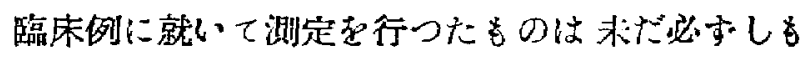
多くはないので，著者は立に Daughaday 氏法に 則り，凡之 100 例に集了各程疾患に就いて所謂尿 中 Formaldehydogenic Corticoids(以下 FC 之略

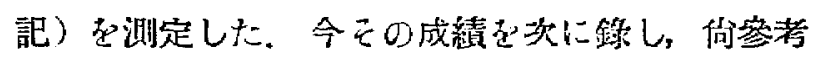
として测定した總中性17 Ketosteroids 量(以下17 KS と略訅)をも併せ揭げる.

\section{军 驗}

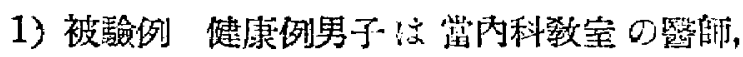

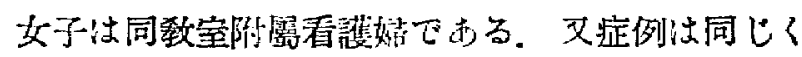

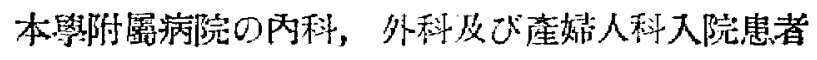

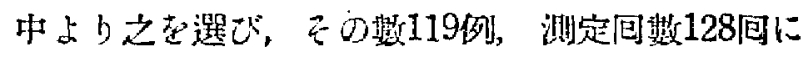

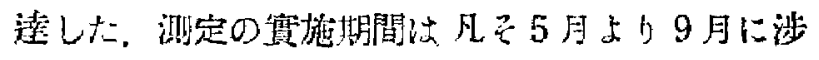
ot.

2) 测定方法 FC 训定. Daughaday 氏法に淮 した，但しょり之を符易にし，尿 $200 \mathrm{cc}$ (尤或量

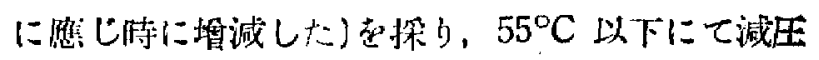

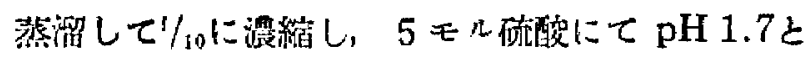

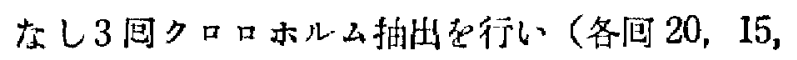
10cc), クロロホルム蒸發, 残澘をぺンゼンにて

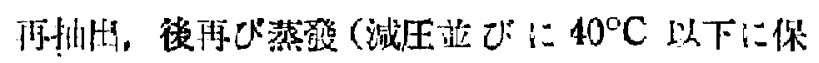


つ), 次いで少量のベンゼン(總量 $2 \mathrm{cc}$ )で共栓遠 心管に移し，之を $5 \mathrm{cc}$ の水にて振壍抽出，その4

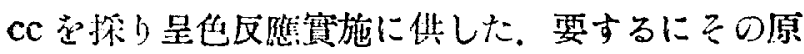
法已些か異りしはク口ロホルムに於ては使用量を 原法の䄪 $1 / 10$ ，ベンゼンでは約 $1 / 3$ の少量に止めた

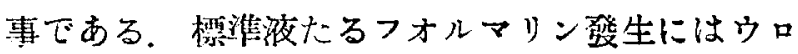
トロビン純品を用い, Leifo の此色計でフイル夕 -510の使用の下に测定した。

$17 \mathrm{KS}$ 测定. Drekter 岻等の方法により水解抽 出を行い，Pincus 氏等の方法によりミクロジラ 一ル分劃を行つて非ケトン部を除き，ケトン部の みに就きPearson 氏等の方法により呈色反應を 行つた. $17 \mathrm{KS}$ の呈色には或は三塩化アンチモン 及び醋酸を用いる Pincus 氏法, 或は Zimmermann のメタジニトロベンゼン反應を㗹用した Callow 又は Holtorff の法があるが, Pincus 氏 法で注呈度弱 \}, Callow 氏法では每常必すし る一定せる結果を得ること難く，叉盲驗值が僅か 乍ら陽性に得られるので，試葬調裴上簡易ですあ り，上訅の各種久点の少い Holtorff 氏法る探つ た、標準にはデヒドロイソアンドロステロンを用 い，Leifo の比色部でフイルター460を用い測定し た。

霓驗成績
次に测定成綪を疾患别に揭げる，下記表中 FC 並びに17 KS の量は1日に排洴せられた總量でお る.

1）揵康人例 健康人例:於いてはFC 汶男女 共 $\mathrm{i}$ 乃至 $2 \mathrm{mg}$ pro die 0 籍圄內にあb，之治 Daughaday の成績と一致する。

\begin{tabular}{|c|c|c|c|c|c|c|}
\hline 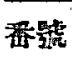 & 姓 名 & 性 & 年 剩 & $\mathrm{FC} \mathrm{mg}$ & $\begin{array}{c}17 \mathrm{KS} \\
\mathrm{mg}\end{array}$ & 尿量cc \\
\hline 1 & & $\hat{o}$ & 30 & 2.45 & 12.6 & 1440 \\
\hline$\overline{2}^{-}$ & & 7 & 29 & 2.07 & 8.8 & 1750 \\
\hline 3 & & $"$ & 24 & 1.87 & 12.5 & 1670 \\
\hline 4 & & $"$ & 27 & 1.69 & 12.8 & 1750 \\
\hline 5 & & " & 25 & 1.56 & 10.7 & 1680 \\
\hline 6 & & 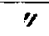 & 25 & 1.41 & 12.2 & 1010 \\
\hline 7 & & " & 28 & 1.26 & 5.6 & 540 \\
\hline 8 & & " & 28 & 1.24 & 7.9 & 940 \\
\hline 9 & & $"$ & 28 & 1.17 & 6.5 & 850 \\
\hline 10 & & 7 & 24 & 1.14 & 8.2 & 1270 \\
\hline 11 & & 7 & 29 & 0.97 & 6.6 & 1500 \\
\hline 12 & & 우 & 21 & 1.89 & 7.4 & 1940 \\
\hline 13 & & $"$ & 21 & 1.62 & 10.5 & 1040 \\
\hline 14 & & $"$ & 19 & 1.57 & 7.2 & 905 \\
\hline 15 & & $"$ & 21 & 1.48 & 8.8 & 900 \\
\hline 16 & & $"$ & 23 & 1.40 & 6.6 & 980 \\
\hline$\overline{17}$ & & 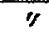 & 22 & 1.27 & 12.8 & 790 \\
\hline 18 & & " & 19 & 1.24 & 5.5 & 1240 \\
\hline 19 & & $"$ & 21 & 1.23 & 5.2 & 790 \\
\hline
\end{tabular}

$17 \mathrm{KS}$ 没平均男子に於て $9.5 \mathrm{mg}$ ，女子に於て 8.0 mg，一般に男子に於て高い傾向を有する。

FC そ $17 \mathrm{KS}$ の相關關係は一見して餘り明膫な るものはない。

\begin{tabular}{|c|c|c|c|c|c|c|c|c|c|c|c|}
\hline 番 號 & 姓 名 & 性 & 年 & 跲 & 病 & FC mg & $17 \mathrm{KS} \mathrm{mg}$ & 尿 & 備 & & 考 \\
\hline 1 & & ? & & & 日本嘼类 & 3.66 & 8.0 & 880 & $\overline{\text { 發 }}$ & 熱 & '期 \\
\hline 2 & & 8 & & & 腸チフ & 3.28 & 11.1 & 2200 & & 18 & \\
\hline 3 & & $\delta$ & & & 流行性䏦资 & 4.60 & 9.1 & 1100 & & " & \\
\hline 4 & & $\hat{o}$ & & & 7 & 1.72 & 3.5 & $50 \mathrm{~J}$ & 無整, & 黄造 & क \\
\hline 5 & & $\hat{o}$ & & & " & 1.70 & .9 .3 & 1240 & & $"$ & \\
\hline 6 & & 우 & & & $"$ & 0.36 & 8.2 & 850 & 逞 & 延 & 型 \\
\hline
\end{tabular}

2）㥯性傳染病 日本胉炎, 腸チフス, 流行性汗 炎各1例の發病して間もない伤熱期にそれぞれFC の甚だ高い值を認めた事は，所謂ストレッスに對 する副腎の反應之解して理解できぬ事はない，流 行性汗炎の既に解熱せるものに於ては正常值であ つた. 最後の和氣例は發病後經過著るしく遷延
し、バイオプシーにより旰のフイブロージスな來 せる事在證しており，之は别の意味に於て興味が ある例である。

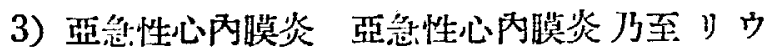
マチ性心內膜炎かと解せられた2例に於て，同し く FC の增量を認めた事を上記急性傳染病に於汀

\begin{tabular}{|c|c|c|c|c|c|c|c|c|c|c|c|}
\hline 番 號 & 姓 & 名 & 性 & 年 & 龄 & 病 & $\mathrm{FC} \mathrm{mg}$ & $17 \mathrm{KS} \mathrm{mg}$ & 尿量 & 備 & 考 \\
\hline 1 & & & q & & & 亞急性心內膜华（リウマチ？） & .55 & 2.0 & 1450 & & \\
\hline 2 & & & $\delta$ & & 4 & 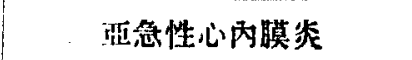 & 3.08 & 8.7 & 1450 & & A \\
\hline
\end{tabular}




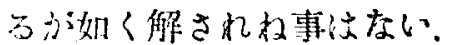

4）リウマチリウマチ第 1 例は堜否な多發性

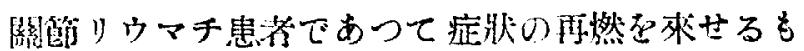

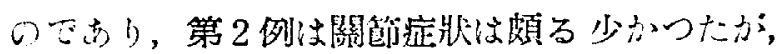
心解炎症將，微熟，解肉痛等不定のチウマチ症狀

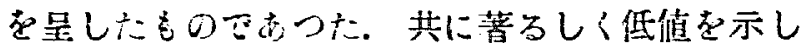

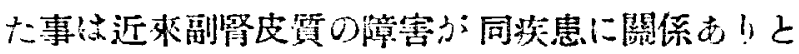

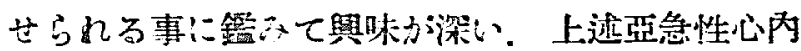

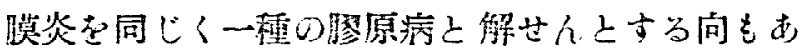
るふ，本症に於て FCお滇だ高くリウマチ㱏に於

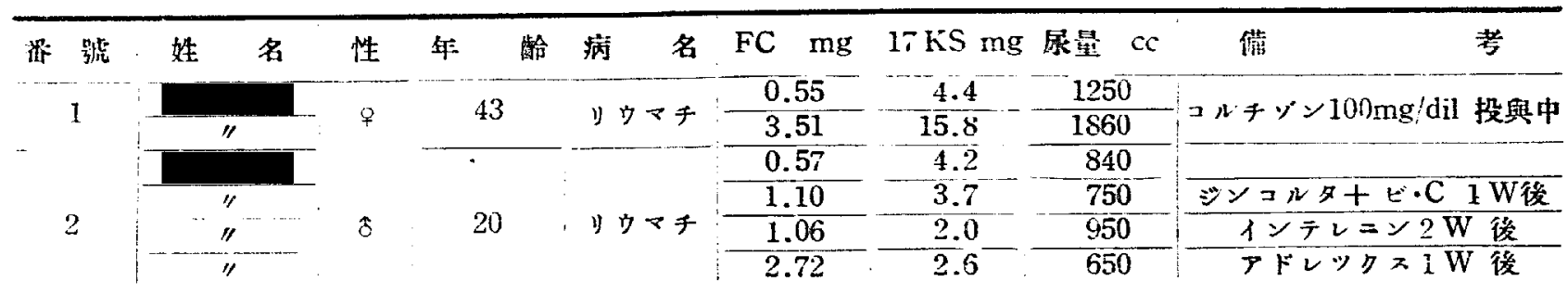

て低い事は之等疾患の辫别に或は役立つかもしれ ない，俱し何分症例与步い事であり，將來の研究

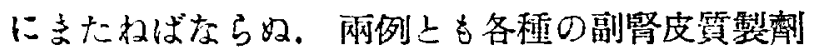
ぬ用いて FC 排泄量の增加している事は當然とは

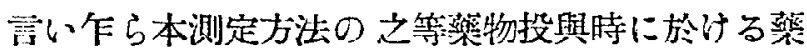
理を明にする上に於て役立ち得る事を物話つてい 子.

5）血行器疾患 2 例の心筋炎に於て共に FC わ: ほぼ正常であつた事は，例えば前記心內膜炎に於 ける FC の燴量が單に血行器不全に關知せす，感 染と密接な關係にある事を示するのであうう。高 血压症例は僅に2例であつたが，FCの増加は認 められなかつた。

\begin{tabular}{|c|c|c|c|c|c|c|c|c|}
\hline 橎號 & 姓名 & 性 & 年跉 & 病名 & $\begin{array}{c}\mathrm{FC} \\
\mathrm{mg}\end{array}$ & $\begin{array}{c}17 \mathrm{KS} \\
\mathrm{mg}\end{array}$ & $\begin{array}{c}\text { 尿量 } \\
\text { CC }\end{array}$ & 備考 \\
\hline 1 & & 음 & 76 & 心筋尖 & 1.95 & 2.7 & 410 & \\
\hline 2 & & 9 & 44 & 高血压 & 1.45 & 8.0 & 960 & \\
\hline 3 & & $\delta$ & 50 & 高面庄 & 0.93 & 8.8 & 1550 & \\
\hline 4 & &.$\delta$ & 48 & 心筋态 & 0.93 & 6.3 & 1100 & \\
\hline
\end{tabular}

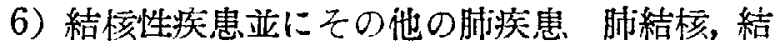
核性腹朕炎，肺境疸に於て FC の低、值を示方

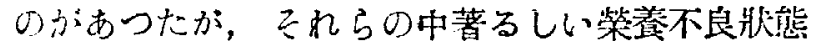
に陷れるものは當然の事としても然らざるものに

\begin{tabular}{|c|c|c|c|c|c|c|c|c|}
\hline 番號 & 姓名 & 性 & 年龄 & 病名 & $\begin{array}{c}\mathrm{FC} \\
\mathrm{mg}\end{array}$ & $\begin{array}{r}17 \mathrm{KS} \\
\mathrm{mg}\end{array}$ & $\begin{array}{c}\text { 尿量 } \\
\text { cc }\end{array}$ & 備考 \\
\hline 1 & & 8 & 24 & 肺秸核 & 2.20 & 11.5 & 1540 & \\
\hline 2 & & $\delta$ & 29 & $" 1$ & 2.18 & 8.1 & 540 & \\
\hline 3 & & 9 & 34 & $"$ & 1.72 & 4.5 & 1120 & \\
\hline 4 & & 9 & 37 & " & 1.57 & 3.4 & 895 & \\
\hline 5 & & 9 & 27 & $"$ & 1.52 & 8.9 & 1130 & \\
\hline 6 & & 9 & $\overline{27}$ & "I & 1.30 & 2.1 & 1000 & \\
\hline 71 & & 8 & 28 & 7 & 1.26 & 6.6 & 1250 & \\
\hline 8 & & 9 & 23 & $" 1$ & 1.26 & 6.9 & 600 & \\
\hline 9 & & $\vec{\delta}$ & 42 & "I & 1.14 & 7.0 & 1760 & \\
\hline
\end{tabular}

\begin{tabular}{|c|c|c|c|c|c|c|c|}
\hline 10 & 3 & 39 & ") & 1.10 & 11.4 & $1340^{\circ}$ & \\
\hline 11 & 0 & 23 & $"$ & 0.96 & 2.7 & 850 & \\
\hline 12 & $\hat{0}$ & $\overline{29}$ & $\pi$ & 0.89 & 7.3 & 720 & \\
\hline 13 & $\frac{0}{q}$ & $\overline{36}$ & " & 0.86 & 4.5 & 1480 & \\
\hline 14 & $\hat{0}$ & 42 & 7 & 0.84 & 10.8 & 1140 & \\
\hline 15 & $\hat{o}$ & 32 & $"$ & 0.68 & 14.8 & 750 & \\
\hline 16 & $\hat{3}$ & 54 & $"$ & 0.67 & 3.1 & 730 & \\
\hline 17 & 家 & 39 & r & 0.65 & 17.6 & 2000 & \\
\hline 18 & $\hat{0}$ & 22 & " & 0.62 & 16.2 & 1210 & \\
\hline 19 & 0 & 27 & $n$ & 0.55 & 5.6 & 1400 & \\
\hline 20 & ? & 27 & $" 7$ & 0.47 & 3.6 & 580 & \\
\hline 21 & $\%$ & 35 & "I & 0.43 & 8.6 & 740 & \\
\hline 22 & 우 & 24 & $"$ & 0.29 & 4.7 & 1140 & 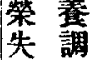 \\
\hline 23 & $\hat{0}$ & $\overline{29}$ & $"$ & $\overline{0.27}$ & $8 . \overline{5}$ & 700 & \\
\hline 24 & $\delta$ & 22 & "I & 0.25 & 4.2 & 620 & \\
\hline 25 & q & 27 & 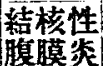 & 1.93 & 9.2 & 1120 & \\
\hline 26 & 우 & 28 & 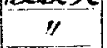 & 0.53 & 2.5 & 380 & \\
\hline 27 & $\hat{o}$ & 35 & 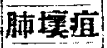 & 1.52 & 4.6 & 1380 & \\
\hline 28 & $\delta$ & 50 & " & $\overline{0.47}$ & 2.6 & 2550 & \\
\hline 29 & 9 & 40 & $"$ & 0.41 & 4.1 & 910 & \\
\hline
\end{tabular}

於て，折々おつる事方認められた事は今啳更に檢 討正要する。斯くの如き慢性傳染性奖患に於ける

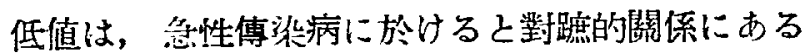
ちののようである。

7) 消化器疾患(癌后除く) 周浩将, 無酸症に於 て FC は餘り藷變がない. $17 \mathrm{KS}$ は一般に低い様 だある。

\begin{tabular}{|c|c|c|c|c|c|c|c|c|}
\hline 番號 & 姓名 & 性 & 年龄 & 病名 & $\begin{array}{l}\mathrm{FC} \\
\mathrm{mg}\end{array}$ & $\begin{array}{r}17 \mathrm{KS} \\
\mathrm{mg}\end{array}$ & $\begin{array}{c}\text { 尿量 } \\
\text { CC }\end{array}$ & 储考 \\
\hline 1 & & $\delta$ & 61 & 胃溃瘇 & 2.70 & 5.1 & 910 & \\
\hline 2 & & 3 & 34 & " & 1.95 & 4.4 & 820 & \\
\hline 3 & & 3 & 52 & $"$ & 1.71 & 5.4 & 800 & \\
\hline 4 & & $\delta$ & 22 & $"$ & 1.15 & 8.7 & 940 & \\
\hline 5 & & $\hat{o}$ & $\overline{19}$ & $" 1$ & 0.91 & 1.4 & 1400 & \\
\hline 6 & & $\hat{\delta}$ & 32 & " & 0.89 & 6.6 & 610 & \\
\hline 7 & & 3 & 25 & " & 0.47 & 5.9 & 1160 & \\
\hline 8 & & 9 & 24 & 㩏酰症 & 1.01 & 4.8 & 560 & \\
\hline 9 & & 9 & 27 & $" 1$ & $0 . \overline{95}$ & 5.1 & $1090^{\circ}$ & \\
\hline
\end{tabular}


8）晹符生出症 钩虫症に於ては FC の排泄が 正常臈图である.

\begin{tabular}{|c|c|c|c|c|c|c|c|c|}
\hline 潘躆 & 姓名 & 性 & 年龄 & 满名 & $\begin{array}{c}\mathrm{FC} \\
\mathrm{mg}\end{array}$ & $\begin{array}{c}17 \mathrm{KS} \\
\mathrm{mg}\end{array}$ & $\begin{array}{c}\text { 厡量 } \\
\mathrm{cc}\end{array}$ & 備考 \\
\hline 1 & & q & 41 & 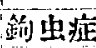 & 2.28 & 3.9 & 560 & \\
\hline 2 & & q & 43 & "I & 1.80 & 3.4 & 690 & \\
\hline 3 & & 9 & 35 & " & 1.18 & 9.4 & 1370 & \\
\hline
\end{tabular}

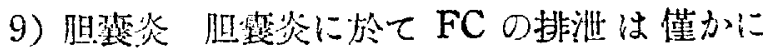
增加倾向に志る事が見られた。

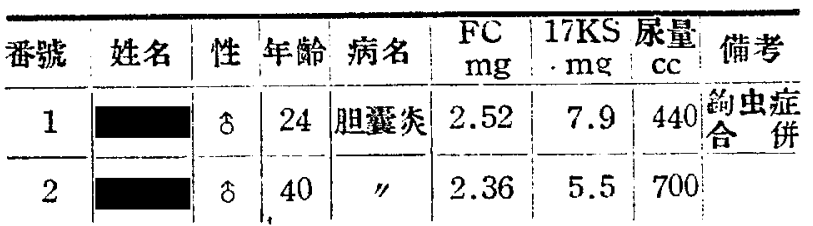

10）泌尿器疾患 腎炎に於ては FCの排泄は高 低區々であつた。

\begin{tabular}{|c|c|c|c|c|c|c|c|}
\hline & 姓名 & 性 & 年龄 & 病 & $\begin{array}{c}\mathrm{FC} \\
\mathrm{mg}\end{array}$ & $\begin{array}{r}17 \mathrm{KS} \\
\mathrm{mg}\end{array}$ & 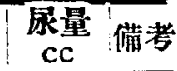 \\
\hline & & ( & 24 & 督 & 2.60 & 8.4 & 920 \\
\hline & & $\hat{\delta}$ & & & 0.70 & 5.5 & 550 \\
\hline
\end{tabular}

11）內分泌疾患 內分泌疾患でば゙セドゥー氏 病に於て概して FC の䔎だ高い事は從來むまり研 笁者の知つていない所である，更に糖尿病に於て

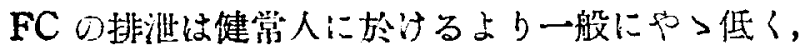
之に反してインシュリン過多症かと思われる1例 に於て FCの高い排泄量を認めた事も記憶に値す る. 畟体殘留症に於的る FC の低值は或は下垂体

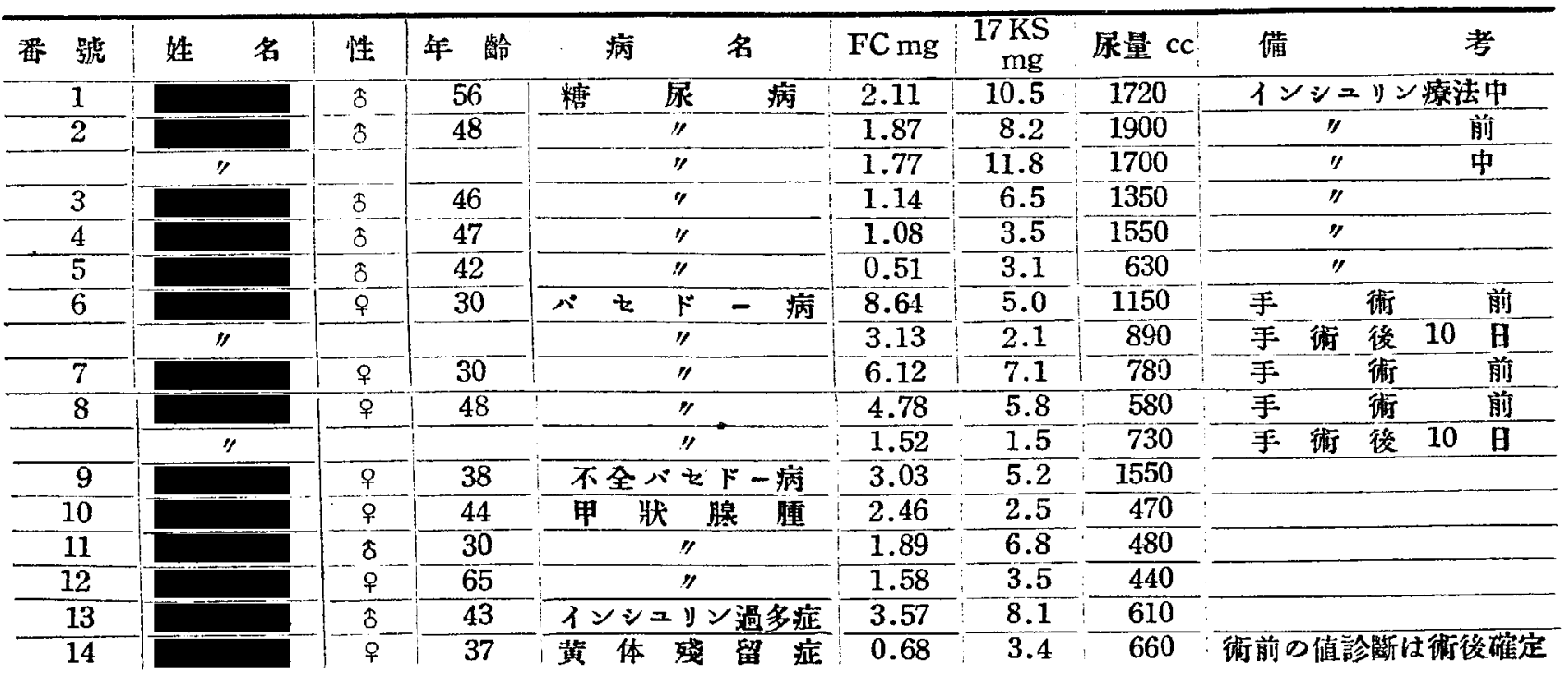

ホルモンの分泌異常を示するの数.

12）血液疾患 FCの萠だ高い值は售種の血液 疾患に認められたが，さすがに再生不良性貧血で
は正常或は低值を示した，1例の溶血性黃誼に於 て剔脾後 FC の藷るしい排泄增加が認められた事 も，將來の研究に重要な材料を呈するちのである

\begin{tabular}{|c|c|c|c|c|c|c|c|c|}
\hline 番 & 姓 名 & 性 & 年敬 & 病 & FC mg & $17 \mathrm{KS} \mathrm{mg}$ & 康量 cc & 考 \\
\hline 1 & & $\delta$ & 57 & 顆粠絴胞減少症 & 7.80 & 10.5 & 1270 & 高整正件 5 \\
\hline 2 & & 9 & 62 & 慢性骨蹎性白血病 & 4.20 & 7.4 & 1550 & \\
\hline 3 & & $\delta$ & 22 & ホチキン氏病 & 3.56 & 3.3 & 830 & \\
\hline 4 & & o & 29 & 打生不良性空血 & 2.10 & 11.3 & 1900 & \\
\hline 5 & & $\delta$ & 25 & " & 0.92 & 12.2 & 970 & \\
\hline 6 & & $\delta$ & 28 & 溶血性监还 & 2.90 & 10.7 & 1850 & \\
\hline & 71 & & & & 6.16 & 10.9 & 1300 & 剔脾後 1 力月 \\
\hline
\end{tabular}

\begin{tabular}{|c|c|c|c|c|c|c|c|c|}
\hline 释 胧 & 姓 名 & 性 & 年 踰 & 名 & $\mathrm{FC} \mathrm{mg}$, & $17 \mathrm{KS} \mathrm{mg}$ & 康量 cc & 俨 \\
\hline 1 & & $\delta$ & 39 & 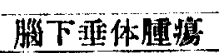 & 6.70 & 3.2 & 2430 & 网更侧牛直件5 \\
\hline 2 & & 9 & 22 & 㙞 胜 & 5.59 & 7.2 & 510 & \\
\hline 3 & & 8 & 52 & 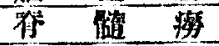 & 4.41 & 16.6 & 1500 & \\
\hline 4 & & $\hat{0}$ & 47 & 腰 梅 & 3.61 & 4.4 & 2150 & \\
\hline 5 & & $\delta$ & 23 & 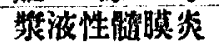 & 0.39 & 5.5 & 1490 & 期 \\
\hline
\end{tabular}


ように思われる。

13）神經柔垁患 腦下重体腫煌の高值住向副腎 皮筫ホルモンの分泌增多を思わせる，春髓疼，腦 椎毒に於て高い值を認めた事は單にストレッスの 如何を以て容易に理解し難いすのがあると思う。

14）癌疾患 惡性腫境心於七胃㿋，肝癌，子宮
癌では 1，2の胃癌の例を除き FC 排泄の正常值 を越えるるのぶなかつたか，肺癌並に乳癌に於て FC 排泄の特に高かつた事仗，之等が果して如何 なる意義を有する加值ちに解釋し難いるのがある 方，成因に關し何等加重大なるすの隌示するか の如くである。

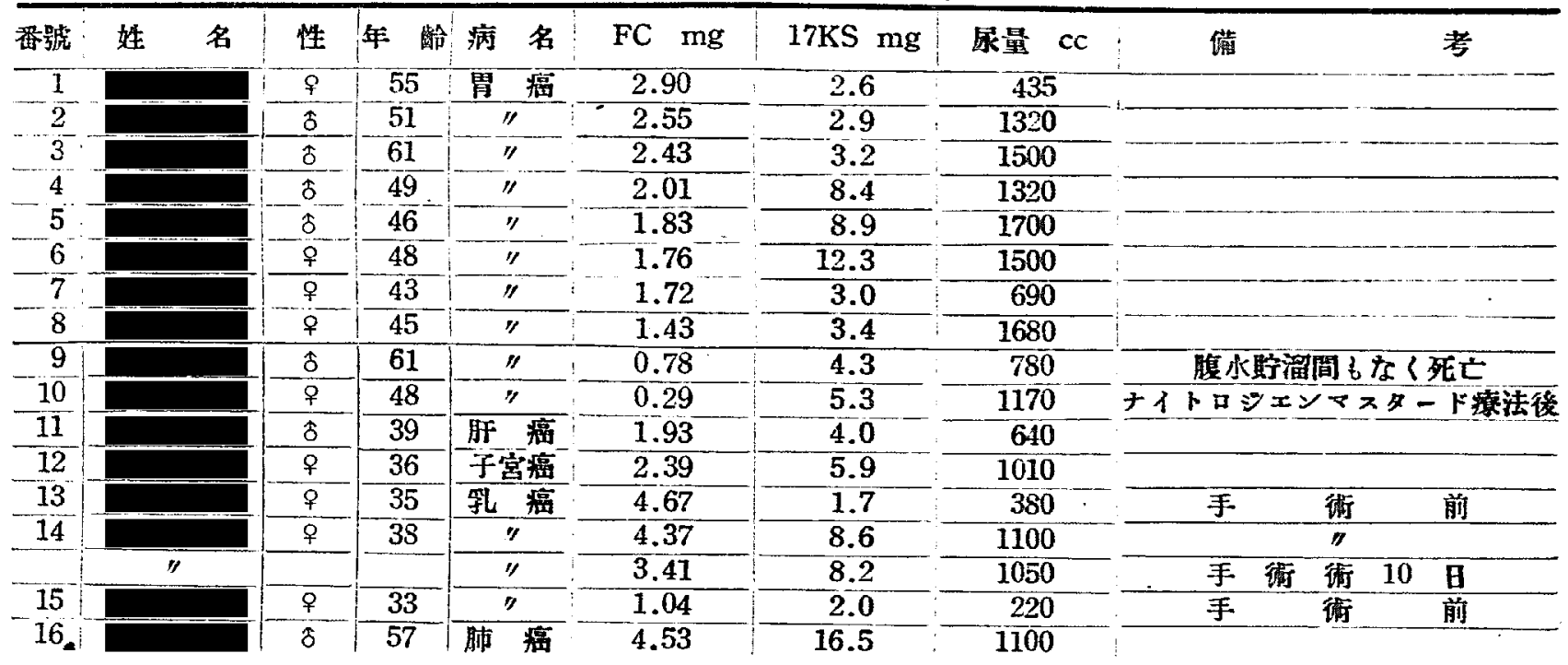

第 1 圆 尿中 Formaldehydogenic Steroids 排洪量

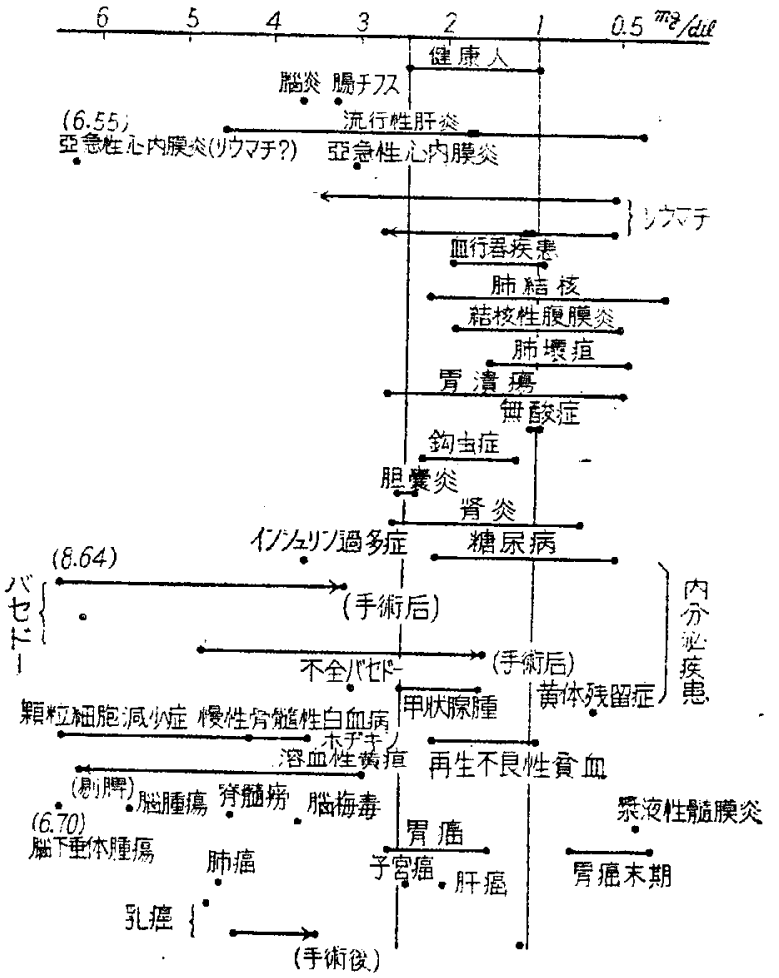

俩17KSに關しては何分健康例に於て最底5.2,
最高12.8邓示し甚しい變差方あり，從つて疾患者 に見られた區々たる高低加直ちに何を意味するす のか，FCの增咸よりも甚しく不鮮明たるを㣻か れない．但し例えば胃癌患者の如きに於て；又肺 結核のあるもの，一般に肺壞瘨，旰癌，甲狀腺矤 患,リウマチ等で低い值をとる傾向が看取されな いではないか，緒諭にも述ハた樣に玆に测定せる 總中﨡 17KS 量は各種のステロイドを包括するす のであり，暫らく樑く觸れない方がよい之思われ る。今參考のため以上の實驗成績を第 1 圖に一括 して揭げる。

\section{總括並びに結論}

著者は各種疾患に於て所謂Fornialdehydogenic Corticoids(FC)並び17Ketosteroids (17KS) の尿 中排泄量を测定し，その增诚に關し次の知識を得 た.

1） FC の排泄增加恤炎，腸チフス，亞急性心 內膜炎，バセドウー氏病，インシュリン過多症， 顆粒細胞诚少症，慢性骨䯠性白血病，ホヂキン，

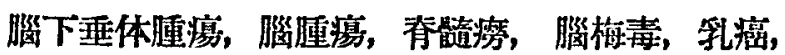
肺癌等に，排泄減少は肺結核，リウマチ，㣴体残 
留症等に之を認めた．高血压，心觔炎，胃潰韵， 無酸症, 鈎虫症, 胆整炎, 督炎, 精尿病, 胃癌等 では FC 排泄量は㱠ど正常籁圍內にあつた，2) $17 \mathrm{KS}$ 汕各種の次患に於て霆々減少をみたが, 殊

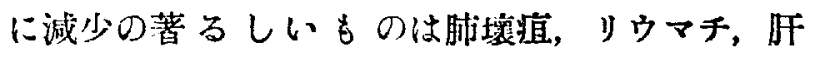
癌，甲狀腺次患等に經驗された。 3) 手術例では バセドウーE病の 2 例に於て FC, $17 \mathrm{KS}$ 共に衙 前の $1 / 2 \sim 1 / 3$ に低下した。溶血性黃㾝の 1 例では剔 脾後 FCは 2 倍强となう，17KS は不㣶であつた。 1 例の乳癌手術例では術後 FC，17KS に著るし，

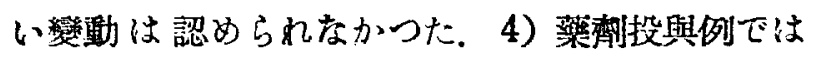
リウマチの 2 例は，投與後 FC はいすれも數倍に
增加している，斟尿病ではインシュリン治療の前 挠に於て FCに㱠ど差を認めなかつた。

\section{文萳}

1) W. Zimmermann: Z. phys. Chem., 233, 257, 1935; 245, 47, 1937.-2) Callow N.H. et al: Bioch. J., 32, 1312, 1938. -3) A.F, Holtorff et al: J. Biol. Chem., 135, 377, 1940. -4) Drekter et al: J. Clin. Endocr., 7, 795, 1947. - 5) G. Pincus et al: Endocrin., 29,413,1941. -6) Pearson et al: J. Clin.Endocri., 8, 618, 1948. 一7) 三宅,㢆谷: 日 內分泌誌, 26, 122, 1950. -8) W.H. Daughaday et al: J. Clin. Endocri., 8, 166, 1948; 8, 244, 1948. -9) H. Selye: Textbook of Endocrinology. -10) Finestone et al: Am:r. Rev. Tbc,. 64, 630, 1951. 